\title{
Application of Business Model Canvas and Blue Ocean Strategy on the Palm Sugar Business Development
}

\author{
Andi Achmad Rizaldy AS ${ }^{1}$, Makkarennu ${ }^{1 *}$, Syahidah ${ }^{1}$ \\ *Faculty of Forestry, Hasanuddin University, Jl. Perintis Kemerdekaan Km. 10 Tamalanrea, Makassar, \\ Sulawesi Selatan, Indonesia
}

\begin{abstract}
Palm sugar is one of the businesses developed widely by the community, mostly those around the forest. The use of sugar palm as a non-timber forest product has been cultivated for generations. However, this business has not been managed as a sustainable business unit with a simple business model. The study aimed to develop a sugar business model through the application of the business model canvas (BMC) and blue ocean strategy (BOS). The business model is applied in the palm sugar business in Sinjai Regency, South Sulawesi, Indonesia. Data collection technique was conducted by using a participatory approach with observation techniques, direct observation of the production, packaging and marketing activities of palm sugar done by palm sugar producers (farmers) at the research location. In-depth interviews using interview guidelines were also conducted to obtain an overview related to the palm sugar business model. Identification of internal environmental factors (IFAS) and external environmental factors (EFAS) was carried out through a SWOT analysis on nine key elements of BMC. The formulation of the business model is conducted by integrating BMC and BOS on the nine elements of BMC in the palm sugar business. The positioning of this business quadrant is in quadrant I with a progressive strategy which means that the palm sugar business is in good condition so it has the potential to grow and can compete with the application of the right business model.
\end{abstract}

Keywords: Palm, palm sugar, BMC, positioning quadran, blue ocean strategy

\section{INTRODUCTION}

The use of non-timber forest products (NTFPs) is one alternative to maintain forest sustainability, where the use of NTFPs is able to reduce the level of people dependence on timber forest products. NTFP products are a source of income as well as direct income to meet the needs of many households and communities [1] [2]. The use of NTFP products which are commonly used, commercialized and become a source of income for the community include rattan, agarwood, honey, essential oils, palm fiber, natural silk, bamboo, eucalyptus, cinnamon, palm sap, palm sugar and so on. [3] [4] [5].

Sugar palm (Arenga pinnata Merr.) is a plant from the palm family and result in many NTFP products which have high economic value because almost all parts of the plant can be utilized and provide financial benefits [6] [7]. One of the derivative products of palm sugar is sap which has the greatest economic value since it is the raw material for making palm sugar [8] [9] [10].

The potential for palm sugar in Indonesia reaches 60,482 ha with palm sugar production of 20,376 tons/year, while the potential for palm sugar in South Sulawesi is 7,293 ha with sugar production of 3,174 tons/year. The latest data regarding the potential of sugar palm in South Sulawesi is still unknown as well as the latest sugar production data are not also still estimated [11] [12].

Sinjai Regency, which is one of the regions in South Sulawesi, has a large enough potential for sugar palm and grows naturally in the region [13],]. There are 6 sub-districts out of 9 sub-districts in Sinjai Regency which have large palm oil potential with a total area of 209.41 ha with a total of 25,866 trees and as many as 693 families who make palm sugar business as their particular job in addition to gardening and other farming businesses. 
DOI: $\underline{10.51386 / 25815946 / \mathrm{ijsms}-\mathrm{v} 4 \mathrm{i} 4 \mathrm{p} 135}$

However, the business has not been able to develop as the business model being carried out is still managed traditionally in both the production and marketing processes. To be able to increase the competitiveness of existing palm sugar products, it is necessary to design a development of business model in the palm sugar entrepreneurship. Thus, it is obligated to make an effort to identify or develop a palm sugar business development strategy using the Business Model Canvas (BMC) which is integrated with the Blue Ocean Strategy (BOS) so that the business can be enhanced and offer increased welfare for the community.

The BMC is a business model concept developed by Alexander Osterwalder and Yves Pigneur and has succeeded in turning a complex business model concept into a simple one. Through the BMC approach, the business model is displayed in one canvas, containing nine elements that can describe the business model that is being carried out. Due to its simplicity, the canvas method can easily assist in analyzing business development strategies, as well as palm sugar businesses [14]. The BMC also helps in describing, analyzing and designing innovative business models in an effort to create, deliver and capture value to be able to enter and create market space and create demand by value innovation [15].

The BOS is a strategy applying control or dominance of market space and does not have any competitors, thus creating irrelevant competition [16]. Blue oceans can result in companies having great potential to earn profits [17]. The BOS is done by exploring demand even though it has a high risk but gives great results [18]. The Blue Ocean strategy launched by Kim and Mauborgne is a perfect extension of analytical tools presented in the form of a robust framework for questioning existing business models and creating new, more competitive models [15]. Based on it it is necessary to conduct research to develop a strategy for developing a business model in the Palm Sugar Business with a Business Model Canvas Approach integrated with the Blue Ocean Strategy which determines the performance of the kind of this business unit. Hence, the palm sugar business is expected to be developed into a sustainable business so as to improve the welfare of the community.

\section{Methods}

\section{A. Study Site}

The research was conducted in Bonto Sinala Village, Sinjai Borong District, Sinjai Regency, South Sulawesi Province. The tools and materials used in the study were a voice recorder used to record the results of interviews conducted with respondents, a camera as a documentation tool in the field, writing instruments to record the results of interviews, and a questionnaire to obtain the required data. There were two sources of data taken in this study, namely primary and secondary data. Primary data were obtained from observations, interviews with palm sugar producers (farmers), middlemen, collectors, and consumers involved in marketing palm sugar. The type of collection data was related to business model mapping based on BMC, comprising customer segments, value propositions, channels, customer relationships, revenue streams, key resources, main activities, partnership relationships, and cost structures. In addition, the information to be explored was internal environmental factors (strengths and weaknesses) and external environmental factors (opportunities and challenges) affecting the palm sugar business unit. Secondary data were obtained through the relevant literature to this research. These data were sourced from research reports, textbooks, and journals. The secondary data needed were the general condition of the research location and the socio-economic of the Bonto Sinala Village community and external factors influencing the palm sugar business.

\section{B. Data Collection Technique}

The phases of research activities were conducted by observation such as direct observation of activities. Data collection methods were done through quantitative methods with a descriptive approach. The population in this study were palm sugar producers (farmers) in Bonto Sinala Village. In this study, the sampling technique was a purposive sampling technique, each subject taken from the population was selected intentionally with certain objectives and considerations. The respondents consisted of palm sugar producers (farmers), traders and local government. Data collection was undertaken by using a participatory approach with observation techniques, direct observation of the production, packaging and marketing activities of palm sugar carried out by palm sugar producers (farmers) at the research location. In-depth interview method using interview guidelines was to obtain an overview related to the palm sugar business model run by palm sugar producers (farmers). Literature Study, namely the collection of secondary data that supports research which includes, among others, the general condition of the location and other supporting data. Documentation, taking pictures on the object of research to provide a clearer and detailed picture of the research topic to be discussed. 
DOI: $\underline{10.51386 / 25815946 / \mathrm{ijsms}-\mathrm{v} 4 \mathrm{i} 4 \mathrm{p} 135}$

\section{Data Analysis}

The data analysis used in the research were:

1. Mapping business models, mapping business model craftsman effort palm sugar palm sugar in Bonto Sinala done through a preliminary analysis of BMC on nine key elements which customer segments, value propositions, channels, customer relationships, revenue streams, key resources, the main activities, partnership relationships, and fee structures.

2. Analysis of external and internal environmental factors. Identification of internal environmental factors (IFAS) and external environmental factors (EFAS) in palm sugar business is undertaken through the SWOT analysis method which was used to identify internal environmental factors and identify external environmental factors in nine key elements of BMC.

3. Evaluation of the nine elements of BMC, the evaluation of the nine elements of BMC uses two analyzes, including an internal analysis carried out to obtain the strength factors to be used and the weaknesses factors to be anticipated. Meanwhile, external analysis was conducted to develop opportunity factors which can be exploited and threat factors that need to be avoided. To evaluate these factors, weighting, rating, and scoring done on each IFAS and EFAS matrices.

4. Business model formulation. After getting the results from previous analyzes, the last stage was the design phase for developing the right business model used by palm sugar business units based on the perspective of Blue Ocean Strategy (BOS).

\section{RESULT}

\section{A. Business Model Mapping}

The initial phase in the preparation of a business model in the palm sugar business use the Business Model Canvas where by mapping and knowing the initial description of the nine elements in the BMC. The following is a description of the nine BMC elements in the palm sugar business:

1. Customer Segment

Customer Segment is the most important aspect in a business unit, without knowing who our customer segment is, a sale and purchase transaction will not occur. Finding out who you want to reach or serve is of course very profitable for a business unit in carrying out its activities by deciding which segments to serve and which to ignore [15]. Likewise with the palm sugar business in Bonto Sinala Village. Palm sugar which is cultivated in the form of molded sugar and palm sugar. Customer segmentation in this business is segmented market and mass market system (open market). Market segmentation is aimed at collecting traders and some people who have become customers. In addition to market segmentation, this business also uses an open market system, meaning that it does not limit its customers to access its products. The mass market is aimed at consumers who can directly access (local market) palm sugar products. In some palm sugar producers (farmers), the segmentation of the customers or the customer segment is the collecting traders. They sell their palm sugar to collectors who are then brought to the market for resale and then to consumers. The flow of the palm sugar market chain is illustrated as shown in Figure 1.

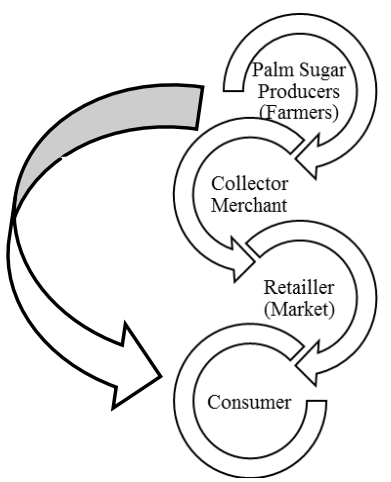

Figure 1. Palm Sugar Market Flow

2. Value Propositions

Value Propositions are the reasons which make customers switch from one merchant to another. Value proposition can solve customer problems or satisfy customer needs. Each value proposition consists of a particular combination of products or services that cater to the needs of specific customer segments that traders can take advantage of to offer to customers [15]. The value proposition of a product or service 


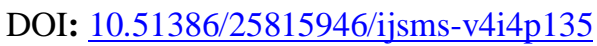

describes a product or service that is created to provide and produce specific value for its customers. The value offered by the palm sugar business, both block sugar and palm sugar, is the accessibility or affordability of collectors who are easier to collect palm sugar produced by palm sugar producers (farmers). Collectors will come to palm sugar producers (farmers) to buy their sugar. In addition, the palm sugar that is made does not use chemical preservatives that are harmful to health, they only use natural ingredients in the tapping process and the cooking process of palm sugar. On the other hand, product quality is further improved by complying with the SNI Palma Sugar standard (SNI 01-3743-1995) where the water content of block sugar is below $10 \%$ while palm sugar is $2 \%$.

3. Channels

Channels are a description of how a merchant's product is delivered to its customers and reaches them to provide the value proposition offered. Human resources of the company play an important role in the channel element because customers still want to meet with manufacturers to ask for product information or solve problems that may exist related to [15]. Channels carried out by palm sugar producers (farmers) are divided into two types, namely through collectors (indirect selling) and direct sales to customers (direct selling). Most of the distribution of the products produced is through collectors or indirectly to final consumers. Products produced by palm sugar producers (farmers) are directly distributed to collectors. Direct selling is also carried out by palm sugar producers (farmers) by bringing directly to customers/consumers who have become subscriptions. The marketing process for this palm sugar product has not utilized existing information technology such as online marketing.

4. Customer Relationships

The type of this relationship is to be built between merchants and consumers in order to collaborate in terms of running a mutually beneficial business. Achieving the level of customer satisfaction is the main target of marketing. Hence, the entrepreneur should provide better service than competitors who exceed consumer expectations by implementing customer relationship management. Customer relationship is one of the business approaches based on managing relationships or relationships with customers so that it is hoped that entrepreneurs/traders can encourage the creation of a loyalty [15]. The customer relationship applied by palm sugar producers (farmers) is a personal relation where the seller and buyer in this case are between palm sugar producers (farmers) and collectors as well as direct buyers. The personal relationship that exists is in the form of a trusting relationship between palm sugar producers (farmers) and their customers. For example, to obtain palm sugar produced by palm sugar producers (farmers), customers can contact directly either by going directly to the palm sugar craftsman's house or by telephone communication. On the other hand, palm sugar producers (farmers) can also contact their customers directly, either by telephone or through individuals who they consider to be familiar with their customers, especially if the product ordered by the customer is ready to be transported.

5. Revenue Streams

Revenue Streams are income or receipts obtained by palm sugar producers (farmers) from their sales or from their customers. Revenue streams are at the core of the business model. The revenue stream element describes the income stream obtained by entrepreneurs/traders from each customer [15]. In this palm sugar business, the price mechanism used is fixed menu pricing where the price is set based on the volume/quantity of the product. The income obtained is in the form of the sale of block sugar to collectors who are sold at prices ranging from IDR 13,000 - IDR 15,000 while palm sugar is sold at a price range of IDR 35,000 - IDR 40,000. Although the direct selling price is higher than the price obtained by collecting traders, palm sugar producers (farmers) sell more of their products to collectors because of the certainty of purchasing the sugar. The amount of revenue from the sale of palm sugar through traders is IDR 130,000 per day, or IDR 47,450,000 per year. Thus, after deducting the costs incurred including equipment costs (IDR $3,000,000$ ) and other unexpected costs (IDR 1,000,000), the income received by the sugar maker is IDR $43,450,000$ assuming 1 production house. done by 2 people, then the income per person is IDR 21,725,000 per year or IDR 1,810,417 per month.

6. Key Resources

Key Resources are entrepreneur/trader resources needed by business units to create and offer value propositions, reach markets, maintain relationships with customer segmentation and generate revenue. The main resources can be seen from three elements, namely physical (equipment and raw materials), intellectual (brands and partnerships), labor and finance [15]. The main resources owned by this palm sugar business consist of raw materials (palm plants), equipment and materials for processing palm sugar, human resources (HR) and market channels. The palm plant is a producer of sap as the main raw material in the manufacture 


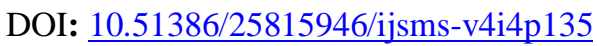

of palm sugar. Other main resources used are palm sugar processing equipment and materials consisting of ladders, sap storage containers, machetes and knives, cooking pans, stoves, firewood and printing equipment. While the workforce generally comes from family members of the palm sugar maker itself, so it does not require capital expenditure in the payment of labor. In running this palm sugar business, market channels play an important role as a resource that collects products from the palm sugar processing.

7. Key Activities

Key Activities are the most important activities carried out by entrepreneurs/traders so that businesses run according to plan and can operate successfully. The main activity describes the important activities that affect pricing, these activities can be in the form of production, distribution, design, and sales. The main activities can also be categorized into three things, namely product operations (design, innovation, product manufacture), service operations (problem solving) and platforms and networks [15]. The main activities carried out by palm sugar producers (farmers) include processing palm sap into block palm sugar and palm sugar. The palm sugar processing process is carried out in several stages, namely, starting from the process of tapping palm sap, cooking the sap into sugar, grinding, packaging and sales. The process of tapping palm sap is done twice a day, at $07.00 \mathrm{am}$ and $17.00 \mathrm{pm}$. [20] The tapped palm trees are harvested in the morning and evening, then the raw materials are transported directly to the palm sugar production house. Meanwhile, the process of cooking palm sap into sugar is carried out twice in the cooking process, the first time after taking the afternoon sap which is cooked so that the taste does not turn into palm juice, then continued to be cooked with the results of the tapped sap in the morning. Moulding or grinding and packaging is done after the sap is cooked and then block in special containers or molds from coconut blocks then dried and then wrapped using plastic. As for the palm sugar, after the palm sap is cooked, it will then be transferred from the furnace to another place and then cooled, the palm sugar continues to be stirred, until it forms granules which are then ground until smooth evenly. After that, it is packaged using plastic packaging. The palm sugar processing process can be seen in the image below. After that, it will be marketed according to the existing customer segments, namely by direct marketing and marketing to middlemen.

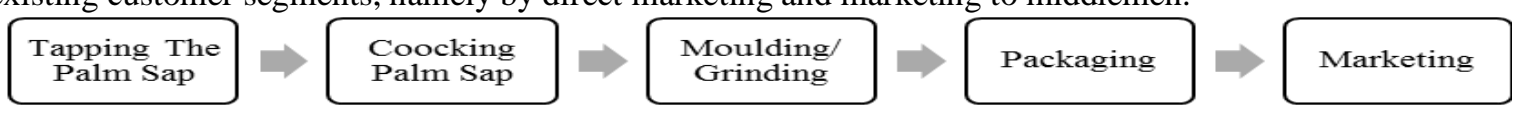

8. Key Partners

Figure 2. The Main Activities of Palm Sugar Processing

Key Partners is a network of suppliers and partners that make business models work. Entrepreneurs/traders form partnerships for a variety of reasons, and partnerships become the cornerstone of various business models to reduce risk or acquire their resources. Strategic allionsi non-competitors where the cooperation carried out is to benefit each through activities carried out without feeling rivaled [15]. The partnership built in this palm sugar business is the relationship between buyers and traders to ensure reliable supply. Partnerships built with subscriptions that become direct buyers also play an important role in the sustainability of the palm sugar business. Palm sugar producer have also done partnerships with the government, where if there is a government order both villages and regions to meet the needs of exhibitions and the like.

9. Cost Structure

Cost Structure is all costs incurred from a business unit to operate its business model. In this element it is explained the most important costs that arise when operating a particular business model. Creating and delivering value, maintaining customer relationships and generating revenue, leads to cost.[15] The cost structure incurred by this business is strongly related to production costs. For now, the costs incurred are still minimal because they still use traditional equipment. The costs incurred by palm sugar producer are the purchase of firewood of IDR 750,000 per three months for a year to IDR 3,000,000. then other expenses in the form of rope, bamboo, cauldron and others amounting to IDR 1,000,000 per year. The total expenditure per year from this palm sugar producer is IDR 4,000,000.

\section{B. Existing Business Model of Palm Sugar Business}

Based on the results of the identification of the nine elements in the Business Model Canvas (Figure 3) where the image summarizes previous explanations of BMC elements namely costumer segment, value propositions, channels, costumer relationships, revenue streams, key resources, key activities, key partners, and cost structure. 


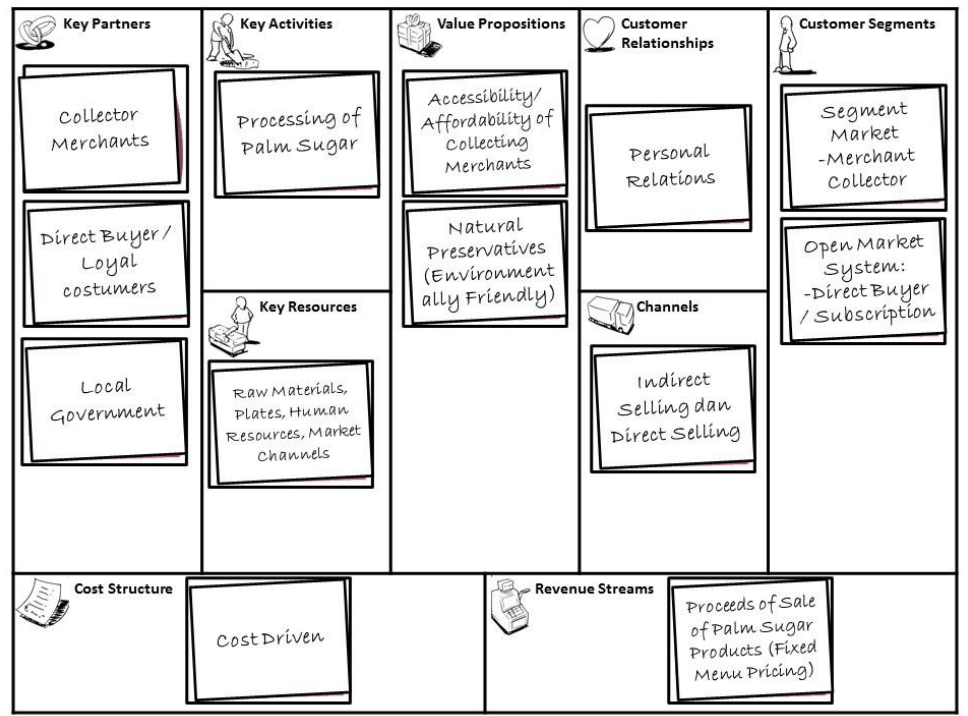

Figure 3. Business Model Canvas Existing on Palm Sugar Business

The business model that has been done before is still very simple where in the nine elements analyzed, this business still maintains the same market segmentation for a long time without any effort to get new customers. Continuity of production is also not guaranteed so there is no target market done. They only produce according to opportunities that exist.

\section{Analysis of Internal and External Factors in Palm Sugar Business}

The analysis used to obtain information related to internal factors and external factors in the nine elements of the Business Model Canvas is SWOT analysis with reference to the results of identification of existing business models that have been obtained before. SWOT analysis provides an explanation of the Strength, Weakness, Opportunities and Threats of the nine elements of BMC in the palm sugar business.

1. Internal Factor Analysis

Based on the results of the analysis conducted on the strengths and weaknesses of the nine BMC elements contained in the palm sugar business, it was obtained results in accordance with Table 1.

Table 1. Internal Factors of BMC Elements

\begin{tabular}{|c|c|c|c|}
\hline \multirow[b]{2}{*}{ No. } & \multirow[b]{2}{*}{ BMC Elements } & \multicolumn{2}{|c|}{ Internal Factors } \\
\hline & & $\begin{array}{l}\text { Strenghts } \\
\text { (S) }\end{array}$ & $\begin{array}{l}\text { Weaknesses } \\
(\mathrm{W})\end{array}$ \\
\hline 1 & $\begin{array}{l}\text { Costumer } \\
\text { Segment }\end{array}$ & $\begin{array}{l}\text { The existence of permanent costumers (merchant } \\
\text { collectors and loyal constumers) }\end{array}$ & $\begin{array}{l}\text { Purchases made erratically every day (number of } \\
\text { buyers) }\end{array}$ \\
\hline 2 & $\begin{array}{l}\text { Value } \\
\text { Proposition }\end{array}$ & Natural preservatives in the manufacture of palm sugar & $\begin{array}{l}\text { The form of palm sugar produced by both block } \\
\text { sugar and palm sugar is less attractive, packaging } \\
\text { is less attractive }\end{array}$ \\
\hline 3 & Chanels & The low budget of marketing & The limited access to marketplace \\
\hline 4 & $\begin{array}{l}\text { Customer } \\
\text { Relationships }\end{array}$ & $\begin{array}{l}\text { Personal relationships of mutual trust are established } \\
\text { between sugar producers (farmers) and collecting } \\
\text { merchants and subscriptions. }\end{array}$ & $\begin{array}{l}\text { Reliance on collecting merchants and subscriptions } \\
\text { that has an impact on the acquisition of limited } \\
\text { buyers }\end{array}$ \\
\hline 5 & Revenue Streams & $\begin{array}{l}\text { Palm sugar products sold to collectors and existing } \\
\text { constumers (with regular customers, revenue streams can } \\
\text { be projected) }\end{array}$ & $\begin{array}{l}\text { Revenue depends only on the proceeds of the sale } \\
\text { of palm sugar (Price stamping depends on } \\
\text { collecting merchants) }\end{array}$ \\
\hline 6 & Key Resources & Availability of raw materials and labor & $\begin{array}{l}\text { The equipment used is still sober, so it affects the } \\
\text { quality of the product. }\end{array}$ \\
\hline 7 & Key Activities & $\begin{array}{l}\text { Processing of palm sap into block sugar and palm sugar } \\
\text { (the production process runs continuously) }\end{array}$ & Traditional product packaging tendency \\
\hline 8 & Key Partners & $\begin{array}{l}\text { The trusting relationship between the aren craftsman and } \\
\text { his partner }\end{array}$ & $\begin{array}{l}\text { The absence of written ties is the benchmark of } \\
\text { partnership. }\end{array}$ \\
\hline 9 & Cost Structure & The costs incurred are relatively cheap & $\begin{array}{l}\text { Additional costs during the production process due } \\
\text { to reduced fuel availability }\end{array}$ \\
\hline
\end{tabular}

2. External Factor Analysis

Based on the results of analysis conducted by researchers on the opportunities and threats of the nine BMC elements contained in palm sugar efforts, the results are obtained in accordance with Table 2. 
DOI: $\underline{10.51386 / 25815946 / \mathrm{ijsms}-\mathrm{v} 4 \mathrm{i} 4 \mathrm{p} 135}$

Volume: 4 Issue: 4

July to August 2021

https://www.ijsmsjournal.org

Table 2. External Factors of BMC Elements

\begin{tabular}{|c|c|c|c|}
\hline \multirow[b]{2}{*}{ No. } & \multirow[b]{2}{*}{ BMC Elements } & \multicolumn{2}{|c|}{ External Factors } \\
\hline & & $\begin{array}{l}\text { Opportunities } \\
\text { (O) }\end{array}$ & $\begin{array}{l}\text { Threat } \\
\text { (T) }\end{array}$ \\
\hline 1 & $\begin{array}{l}\text { Costumer } \\
\text { Segment }\end{array}$ & The Increasing demand for palm sugar & $\begin{array}{l}\text { There is competition between palm sugar in other } \\
\text { regions }\end{array}$ \\
\hline 2 & $\begin{array}{l}\text { Value } \\
\text { Proposition }\end{array}$ & $\begin{array}{l}\text { Public awareness inclines in healthy lifestyle by } \\
\text { consuming natural brown sugar products. }\end{array}$ & $\begin{array}{l}\text { Similar products from various regions are of better } \\
\text { quality, and high quality }\end{array}$ \\
\hline 3 & Chanels & $\begin{array}{l}\text { The development of communication technology can } \\
\text { make it easier for palm sugar producers (farmers) and } \\
\text { their partners to communicate. }\end{array}$ & $\begin{array}{l}\text { The development of information and communication } \\
\text { technology can make partners turn to other palm } \\
\text { sugar producers (farmers). }\end{array}$ \\
\hline 4 & $\begin{array}{l}\text { Customer } \\
\text { Relationships }\end{array}$ & $\begin{array}{l}\text { Product quality will determine customer satisfaction so } \\
\text { that it can provide more new customers (add more loyal } \\
\text { customers) }\end{array}$ & $\begin{array}{l}\text { Customer dissatisfaction with product quality will } \\
\text { cause customers to switch. }\end{array}$ \\
\hline 5 & $\begin{array}{l}\text { Revenue } \\
\text { Streams }\end{array}$ & $\begin{array}{l}\text { Rising demand for palm sugar will add to the potential } \\
\text { income of palm sugar producers (farmers) }\end{array}$ & $\begin{array}{l}\text { The number of palm sugar producer who become } \\
\text { rivals }\end{array}$ \\
\hline 6 & Key Resources & $\begin{array}{l}\text { Government policies in community empowerment } \\
\text { programs can increase the knowledge of palm sugar } \\
\text { producers (farmers) }\end{array}$ & $\begin{array}{l}\text { Continuity of palm sugar production does not run } \\
\text { smoothly without preparing stock / reserves of raw } \\
\text { materials }\end{array}$ \\
\hline 7 & Key Activities & Processing palm sap can use more modern technology & $\begin{array}{l}\text { Lack of palm sugar producers (farmers) skills in } \\
\text { using more modern technology }\end{array}$ \\
\hline 8 & Key Partners & $\begin{array}{l}\text { Support from the local government to make palm sugar } \\
\text { commodities as the superior products of the region }\end{array}$ & $\begin{array}{l}\text { There is no clarity about what support can be } \\
\text { provided by the local government. }\end{array}$ \\
\hline 9 & Cost Structure & $\begin{array}{l}\text { By using modern technology will streamline the time of } \\
\text { processing palm sugar }\end{array}$ & $\begin{array}{l}\text { The use of technology will increase the production } \\
\text { costs incurred by palm sugar producers (farmers). }\end{array}$ \\
\hline
\end{tabular}

\section{Formulation of Business Model of Palm Sugar Business Development}

\section{Evaluation of BMC's Nine Elements}

The steps in compiling the Internal Factor Analysis Summary (IFAS) and External Factors Analysis Summary (EFAS) tables are to determine the weight of each factor from a scale ranging from 0.00 to 1.00 where all weights do not exceed the total score of 1.00. Ratings are rated on a scale ranging from 4 (outstanding) to 1 (poor). The determination of the score on internal factors can be seen from Table 3.

Table 3. Internal Factors Analysis Summary (EFAS)

\begin{tabular}{|l|l|l|l|}
\hline Internal Strategy Factors & Weight & Rating & Score \\
\hline Strengths (S): & & & \\
1. Customer segment & 0.19 & 3.00 & 0.56 \\
2. Value Propositions & 0.08 & 4.00 & 0.32 \\
3. Chanels & 0.08 & 3.00 & 0.24 \\
4. Customer Relationships & 0.12 & 3.00 & 0.37 \\
5. Revenue Streams & 0.09 & 3.00 & 0.26 \\
6. Key Resources & 0.19 & 3.00 & 0.56 \\
7. Key Activities & 0.10 & 3.00 & 0.31 \\
8. Key Partners & 0.09 & 3.00 & 0.26 \\
9. Cost Structure & 0.06 & 3.00 & 0.19 \\
\hline Total & $\mathbf{1 . 0 0}$ & & $\mathbf{3 . 0 8}$ \\
\hline Weaknesses(W): & & & \\
1. Customer segment & 0.16 & 2.00 & 0.33 \\
2. Value Propositions & 0.12 & 2.00 & 0.23 \\
3. Chanels & 0.12 & 2.00 & 0.09 \\
4. Customer Relationships & 0.09 & 1.00 & 0.23 \\
5. Revenue Streams & 0.11 & 2.00 & 0.18 \\
6. Key Resources & 0.09 & 2.00 & 0.18 \\
7. Key Activities & 0.09 & 2.00 & 0.14 \\
8. Key Partners & 0.14 & 1.00 & 0.08 \\
9. Cost Structure & 0.08 & 1.00 & $\mathbf{1 . 6 9}$ \\
\hline Total & $\mathbf{1 . 0 0}$ & & \\
\hline
\end{tabular}

The table above shows the Internal Factors Analysis Summary (IFAS) which consists of 2 internal factors, namely strengths and weaknesses. The total value obtained from the strength factor is 3.08. [21] revealing that 
DOI: $\underline{10.51386 / 25815946 / \mathrm{ijsms}-\mathrm{v} 4 \mathrm{i} 4 \mathrm{p} 135}$

Volume: 4 Issue: 4

July to August 2021

https://www.ijjsmsjournal.org

the weighted average value position is at the value (2.5), the condition indicates that the strength factor in palm sugar efforts is very good at utilizing existing strengths to overcome weaknesses. The power value that is the main strength is the customer segment and the main resource with a value of 0.56 . The next strengths are customer relationships with a value of 0.37 , value propositions with a value of 0.32 , main activities with a value of 0.31 , revenue streams and partnership relationships with the same value of 0.26 , channels with a value of 0.24 and cost structures with a value of 0.19 .

The weakness factor has a value of 1.69. The highest weakness value is in the customer segment with a value of 0.33 . The next disadvantage is that the channel with a value of 0.24 , the value proposition and income stream have the same value of 0.23 , the main resources and main activities also have the same value of 0.18 , the partnership relationship has a value of 0.14 , the customer relationship has a value of 0.09 and the cost structure has a value of 0.08. External factors consisting of opportunities and threat factors are presented in Table 4

Table 4. External Factors Analysis Summary (EFAS)

\begin{tabular}{|c|c|c|c|}
\hline External Strategy Factors & Weight & Rating & Score \\
\hline $\begin{array}{l}\text { Opportunities (O): } \\
\text { 1. Customer segment } \\
\text { 2. Value Propositions } \\
\text { 3. Chanels } \\
\text { 4. Customer Relationships } \\
\text { 5. Revenue Streams } \\
\text { 6. Key Resources } \\
\text { 7. Key Activities } \\
\text { 8. Key Partners } \\
\text { 9. Cost Structure } \\
\end{array}$ & $\begin{array}{l}0.21 \\
0.15 \\
0.07 \\
0.16 \\
0.16 \\
0.09 \\
0.05 \\
0.07 \\
0.05 \\
\end{array}$ & $\begin{array}{l}4.00 \\
4.00 \\
3.00 \\
3.00 \\
4.00 \\
3.00 \\
3.00 \\
4.00 \\
3.00 \\
\end{array}$ & $\begin{array}{l}0.86 \\
0.58 \\
0.20 \\
0.47 \\
0.65 \\
0.26 \\
0.14 \\
0.28 \\
0.15 \\
\end{array}$ \\
\hline Total & 1.00 & & 3.59 \\
\hline $\begin{array}{l}\text { Threats (T): } \\
\text { 1. Customer segment } \\
\text { 2. Value Propositions } \\
\text { 3. Chanels } \\
\text { 4. Customer Relationships } \\
\text { 5. Revenue Streams } \\
\text { 6. Key Resources } \\
\text { 7. Key Activities } \\
\text { 8. Key Partners } \\
\text { 9. Cost Structure } \\
\end{array}$ & $\begin{array}{l}0.12 \\
0.11 \\
0.12 \\
0.16 \\
0.12 \\
0.16 \\
0.08 \\
0.07 \\
0.05\end{array}$ & $\begin{array}{l}1.00 \\
1.00 \\
1.00 \\
1.00 \\
2.00 \\
2.00 \\
2.00 \\
1.00 \\
2.00 \\
\end{array}$ & $\begin{array}{l}0.12 \\
0.11 \\
0.12 \\
0.16 \\
0.25 \\
0.33 \\
0.16 \\
0.07 \\
0.10 \\
\end{array}$ \\
\hline Total & 1.00 & & 1.42 \\
\hline
\end{tabular}

The table above shows the External Factors Analysis Summary (EFAS) which consists of 2 internal factors, namely opportunities and threats. The total value obtained from the opportunity factor is 3.59. [21] it says that the weighted average value position is at value (2.5). the condition indicates that the opportunity factor in palm sugar business is very good in utilizing existing opportunities to overcome the threat. The value of the opportunity that is the main opportunity is the customer segment with a value of 0.86 . The next opportunities are income streams with a value of 0.65 , value propositions with a value of 0.58 , customer relation ships have a value of 0.47 , partnership relationships have a value of 0.28 , main resources have a value of 0.26 , channels have a value of 0.20 , the cost structure has a value of 0.15 and the main activity has a value of 0.14 .

The threat factor has a value of 1.42. The highest threat value is in the main resource with a value of 0.33 , the customer segment with a value of 0.33 . The next disadvantage is that the channel with a value of 0.24 , the value proposition and income stream have the same value of 0.23 , the main resources and main activities also have the same value of 0.18 , the partnership relationship has a value of 0.14 , the customer relationship has a value of 0.09 and the cost structure has a value of 0.08. After conducting efas analysis, the positioning quadrant is obtained so that it can determine strategies for the development of palm sugar business. The positioning quadrant can be seen in the image below. 
DOI: $\underline{10.51386 / 25815946 / i j s m s-v 4 i 4 p 135}$

Volume: 4 Issue: 4

July to August 2021

https://www.ijsmsjournal.org

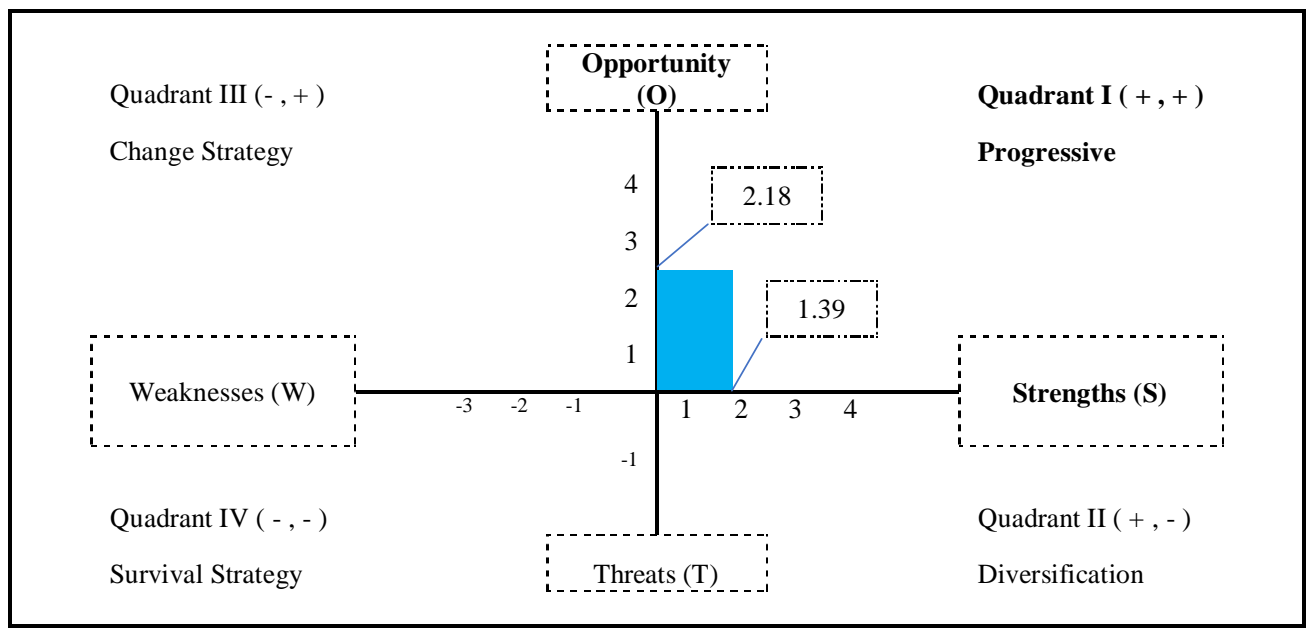

Figure 4. Positioning Quadrant of SWOT

The disadvantage faced by palm sugar makers is that the size of the palm sugar produced is too large, making the sugar less attractive. In addition, the dependence on collecting traders makes available market access limited. Conversely, the opportunity faced by palm sugar makers is with the high need of the community for palm sugar, because of the increasing awareness of healthy lifestyles. In addition, with technology that has developed well makes it easier for sugar makers to communicate and in the process of processing palm sugar.

In quadrant I, the value of positive internal factors (1.39) and the value of positive external factors (2.18), this condition gives an idea that on the external side the opportunities are greater than in the internal side of existing forces. This shows that the condition of the palm sugar business in the Bonto Sinala Village has strong potential and has the opportunity to develop, the strategy recommendations given are progressive meaning that this palm sugar business is in good condition so that it has the potential to grow and be able to achieve maximum progress.

Furthermore, based on the results of the IFAS and EFAS matrices as well as the SWOT positioning quadrants, various possible strategies can be formulated in the formation of marketing strategies to increase palm sugar sales through the SWOT matrix. By using the SWOT matrix, several alternative business unit development strategies can be obtained in the Bonto Sinala Village consisting of S-O strategies that later become a consideration to formulate the right strategy for existing palm sugar business units.

Table 5. The S-O Strategy of Formulation Matrix

\begin{tabular}{|l|l|}
\hline \multicolumn{1}{|c|}{ BMC Elements } & \multicolumn{1}{c|}{ Strength-Opportunities } \\
\hline Costumer Segment & Increasing production by maximizing existing potential \\
\hline Value Proposition & Maintaining the quality of the product by using natural preservatives \\
\hline Chanels & Improving marketing technology by utilizing social media \\
\hline Customer Relationships & Enhancing quality and establish relationships with partners \\
\hline Revenue Streams & $\begin{array}{l}\text { Increasing palm sugar production by marketing palm sugar products through Regional State } \\
\text { Enterprise/Badan Usaha Milik Desa (BUMDes), and other partners }\end{array}$ \\
\hline Key Resources & $\begin{array}{l}\text { Carrying out training so as to maximize the potential of Arenga palm sugar and available } \\
\text { workforce }\end{array}$ \\
\hline Key Activities & $\begin{array}{l}\text { The use of technology can make it easier for palm sugar producers (farmers) to produce and more } \\
\text { efficient in their sugar work }\end{array}$ \\
\hline Key Partners & The need for partners both from producer and with local governments \\
\hline Cost Structure & $\begin{array}{l}\text { The local government is expected to be able to accommodate palm sugar producer with the } \\
\text { provision of more modern technology }\end{array}$ \\
\hline
\end{tabular}

2. Business Model Formulation

After getting results from several alternative business unit development strategies that can be done in the Bonto Sinala Village, it consists of S-O strategies obtained from the SWOT matrix, the last stage is the design stage of developing the right business model used by the palm sugar business unit based on the Blue Ocean Strategy (BOS) perspective. 


\section{DOI: $\underline{10.51386 / 25815946 / \mathrm{ijsms}-\mathrm{v} 4 \mathrm{i} 4 \mathrm{p} 135}$}

Volume: 4 Issue: 4

July to August 2021

https://www.ijjsmsjournal.org

The development of Blue Ocean Strategy as an innovation concept and management business that applies the basic improvement of innovation values to the business that is on the road. Value innovation in BOS is a framework tool whose working principles are the same as SWOT. Components in value innovation are eliminating, reducing, raising and creating. There are four key questions raised in the framework of four actions that call into question the logic of industrial strategy and the business model that has been formed. The results of the merger of Business Model Canvas (BMC) and Blue Ocean Strategy (BOS) can be seen in Table 6. Table 6. Blue Ocean Strategy of Palm Sugar Business

\begin{tabular}{|c|c|c|c|c|}
\hline $\mathrm{BMC} \quad \mathrm{BOS}$ & Eliminate & Raise & Reduce & Create \\
\hline $\begin{array}{l}\text { Costumer } \\
\text { Segment }\end{array}$ & & $\begin{array}{l}\text { Increasing production by } \\
\text { maximizing existing } \\
\text { potential }\end{array}$ & & \\
\hline $\begin{array}{l}\text { Value } \\
\text { Proposition }\end{array}$ & $\begin{array}{l}\text { Maintaining the } \\
\text { quality of the product } \\
\text { by using natural } \\
\text { preservatives }\end{array}$ & & & \\
\hline Chanels & & & & $\begin{array}{l}\text { Improving marketing technology by } \\
\text { utilizing social media }\end{array}$ \\
\hline $\begin{array}{l}\text { Customer } \\
\text { Relationships }\end{array}$ & & $\begin{array}{l}\text { Increasing quality and } \\
\text { establishing relationships } \\
\text { with partners }\end{array}$ & & \\
\hline $\begin{array}{l}\text { Revenue } \\
\text { Streams }\end{array}$ & & $\begin{array}{l}\text { Releasing palm sugar } \\
\text { products through regional } \\
\text { state enterprise } \\
\text { (BUMDes), and other } \\
\text { partners }\end{array}$ & & \\
\hline Key Resources & & & $\begin{array}{l}\text { Carrying out training so } \\
\text { as to maximize the } \\
\text { potential of Arenga palm } \\
\text { sugar and available } \\
\text { workforce }\end{array}$ & \\
\hline Key Activities & & & & $\begin{array}{l}\text { The use of technology can make it } \\
\text { easier for palm sugar producers } \\
\text { (farmers) to produce and more } \\
\text { efficient in their sugar work. }\end{array}$ \\
\hline Key Partners & & $\begin{array}{l}\text { The need for partners both } \\
\text { from producers (farmers) } \\
\text { and with local } \\
\text { governments }\end{array}$ & & \\
\hline Cost Structure & & & & $\begin{array}{l}\text { Collaborating with local authorities } \\
\text { is expected to accommodate palm } \\
\text { sugar producers (farmers) with the } \\
\text { provision of more modern } \\
\text { technology. }\end{array}$ \\
\hline
\end{tabular}

The table above shows the results of business unit development using the Blue Ocean Strategy. The results obtained are in the development of palm sugar business needs to increase production by maximizing existing potential, improving quality and establishing relationships with partners, improving quality and establishing relationships with partners, increasing palm sugar production by marketing palm sugar products through regional state enterprise (BUMDes) and other partners, and needing to improve other partners. In addition, it is also necessary to create marketing technology by utilizing social media, training to maximize the potential of Arenga palm sugar and available labor, the use of technology can make it easier for palm producers (farmers) to produce and more efficient in their work, and the government accommodates palm sugar producers (farmers) by providing more modern technology.

\section{Recommendation of Business Model of Palm Sugar Business}

Based on the results of the identification of the nine elements in business model canvas, IFAS analysis, EFAS and SWOT and Blue Ocean Strategy, it can be seen in Figure 5 where the image can provide an ideal business model picture for palm sugar businesses in Bonto Sinala Village which is summarized in nine elements BMC. 
DOI: $\underline{10.51386 / 25815946 / \mathrm{ijsms}-\mathrm{v} 4 \mathrm{i} 4 \mathrm{p} 135}$

Volume: 4 Issue: 4

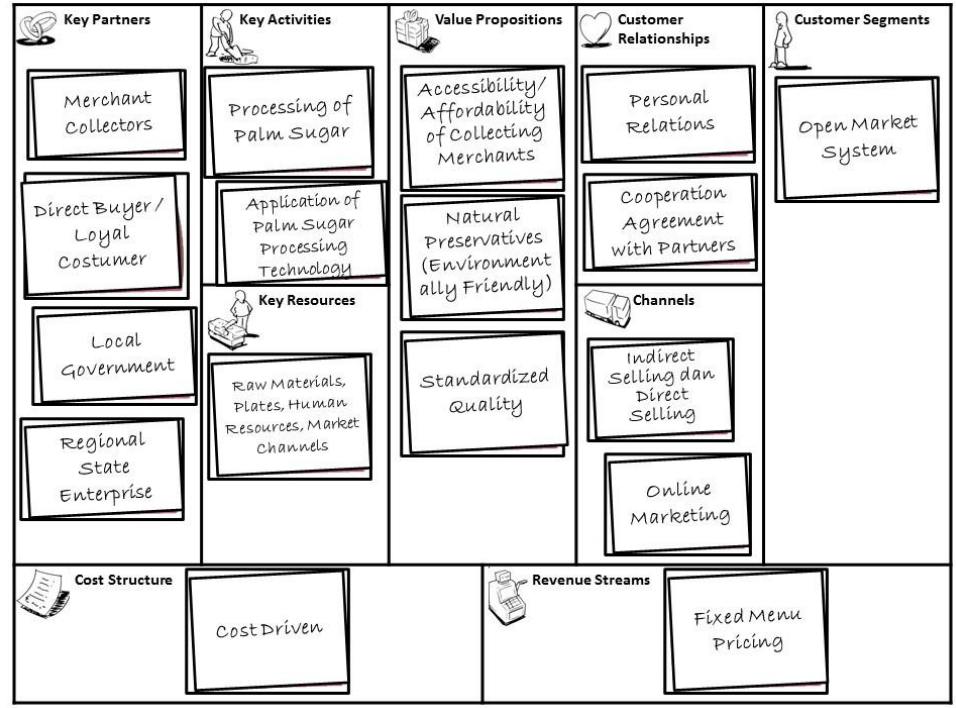

Figure 5. Ideal Palm Sugar Business Model Canvas

Business models that have been updated based on the results of previous analysis, it is expected that by making market segmentation that implements an open market system will get more customers. In addition, the creation of cooperation agreements between producers (farmers) and partners is expected to strengthen customer relationships. Increasing value by meeting standardized quality will further add to the selling value and added value. The application of palm sugar processing technology will be the main activity for producers (farmers), because it will streamline the processing time of the palm sugar. The addition of partners with Regional State Enterprise (BUMD) is expected to facilitate and add to the market network for palm sugar producers (farmers) in Bonto Sinala Village.

\section{Conclusions}

Based on the initial identification results of palm sugar business using Business Model Canvas in Bonto Sinala Village, Sinjai Borong Subdistrict, Sinjai Regency is still classified as a simple business model. The business still maintains the same market segmentation for a long time, without any effort to get new customers. The strengths factor $(\mathrm{S})$ have a score value of 3.08, while the weaknesses (W) have a score of 1.69. It means that this palm sugar business is slightly higher than the strength factor compared to the weakness factor in determining its strategy. In addition, the opportunities factors $(\mathrm{O})$ have a score of 3.59 and threat factors $(\mathrm{T})$ have a score of 1.42. It means that, in an effort to determine this palm sugar business strategy has a higher chance than the threat which would arise. The position of this palm sugar business quadrant is quadrant I (progressive). It shows that the condition of the palm sugar business in Bonto Sinala village has strong potential and opportunity to be developed. To compete with other companies, palm sugar businesses in this region need to apply the use of technology in producing palm sugar and employ information technology in promoting its products by facilitating palm sugar producers (farmers) in producing and more efficient in their sugar work.

\section{REFERENCES}

[1] Wibowo, G. D. H. 2013. Analisis Kebijakan Pengelolaan Hasil Hutan Bukan Kayu (HHBK) di NTB dan NTT. Jurnal Hukum danPembangunan Tahun ke-43 No.2. Mataram.

[2] Karyon, E. Y., Roslinda, E., Riyono, J. N. 2016. Pendapatan Masyarakat Dari Hasil Hutan Bukan Kayu Disekitar Kawasan Cagar Alam Raya Pasi Kelurahan Nyarumkop Kecamatan Singkawang Timur. Jurnal Hutan Lestari 4(3) PP 314 - 321. Pontianak.

[3] Noviantri, A. D. 2011. Kelembagaan Lokal dalam Pemanfaatan Aren dan Peranan Hasil Gula Aren Bagi Pendapatan Rumahtangga Masyarakat Kasepuhan (Desa Sirna Resmi, Kecamatan Cisolok, Kabupaten Sukabumi, Provinsi Jawa Barat).Skripsi pada Departemen Sains Komunikasi Dan Pengembangan Masyarakat Fakultas Ekologi Manusia. Bogor.

[4] Indrasari, D., Wulandari, C., Bintoro, A. 2017. Pengembangan Potensi Hasil Hutan Bukan Kayu Oleh Kelompok Sadar Hutan Lestari Wana Agung Di Register 22 Way Waya Kabupaten Lampung Tengah. Jurnal Sylva Lestari 5(1) PP 81-91. Lampung. 
DOI: $\underline{10.51386 / 25815946 / \mathrm{ijsms}-\mathrm{v} 4 \mathrm{i} 4 \mathrm{p} 135}$

Volume: 4 Issue: 4

July to August 2021

https://www.ijjsmsjournal.org

[5] Tang, M., Malik, A., Hapid, A. 2019. Pemanfaatan Hasil Hutan Bukan Kayu (Hhbk) Bambu Oleh Masyarakat Terasing (Suku Lauje) Di Desa Anggasan Kecamatan Dondo Kabupaten Tolitoli. Jurnal Warta Rimba 7(2). Palu.

[6] Pohan, RM., Purwoko A., dan Martial T. 2014. Kontribusi Hasil Hutan Bukan Kayu dari Hutan Produksi Terbatas bagi Pendapatan Rumah Tangga Masyarakat. Peronema Forestry Science Journal 3(2). Medan.

[7] Pontoh, J. dan Wuntu A. 2014. Perbaikan Proses Pembuatan Gula Merah Aren di Pabrik Gula Aren Masarang Tomohon. Jurnal MIPA Universitas Sam Ratulangi Online 3(2). Manado.

[8] Murtado, Utami S. T. dan Theresia, E. M. 2014. Aren (Arenga pinnata): Investasi Menarik Belum Dilirik. Pusat Penyuluhan Kehutanan. Badan Penyuluhan dan Pengembangan SDM Kehutanan. Kementerian Kehutanan.

[9] Evalia, Nur A. 2015. Strategi Pengembangan Agroindustri Gula Semut Aren. Jurnal Manajemen \& Agribisnis, Vol. 12 (1) : 57 - 67.

[10] Indra, S. B., Gustiana, C., Kulsum, U. 2018. Analisis Keuntungan Usaha Gula Merah Dan Kontribusinya Terhadap Rumah Tangga Di Kecamatan Karang Baru Kabupaten Aceh Tamiang. Jurnal Penelitian Agrisamudra 5(2). Aceh.

[11] Rumokoi, M. M. M. 2004. Aren, Kelapa dan Lontar Sebagai Alternatif Pemenuhan Kebutuhan Gula Nasional. Prosiding Seminar Nasional Aren. Balai Penelitian Tanaman Kelapa dan Palma Lain. Tondano.

[12] Ruslan, S. M., Baharuddin, Taskirawati, I. 2018. Potensi Dan Pemanfaatan Tanaman Aren (Arenga Pinnata) Dengan Pola Agroforestri Di Desa Palakka, Kecamatan Barru, Kabupaten Barru. Jurnal Perennial 14(1) PP 24-27. Makassar.

[13] Dinas Tanaman Pangan, Hortikultura dan Perkebunan. 2017. Potensi Aren di Kabupaten Sinjai. Pemerintah Kabupaten Sinjai.

[14] Iskandarsyah, M. 2013. Analisis Model Bisnis Ekowisata di Pulau Pramuka, Kepulauan Seribu dengan Pendekatan Business Model Canvas. Tesis pada Program Studi Manajemen dan Bisnis, Sekolah Pascasarjana, Institut Pertanian Bogor. Bogor.

[15] Osterwalder, A. dan Pigneur Y. 2017. Business Model Generation. PT Elex Media Komputindo. Jakarta.

[16] Kim, W. C. dan Mauborgne, R. 2015. Blue Ocean Strategy: How to Create Uncontested Market Space and Make the Competition Irrelevant. Boston: Harvard Business School Publishing Corporation.

[17] Dehkordi, G. J., Rezvani, S., Behravan, N. 2012. Blue Ocean Strategy: A Study Over A Strategy Which Help The Firm To Survive From Competitive Environment. International Journal of Academic Research in Business and Social Sciences 2(6). Pakistan.

[18] Ilham, M. N., Wilopo, Mawardi, M. K. 2016. Implementasi blue ocean strategy pada amstirdam coffee (studi kasus pada cv. Pemenang sejati kabupaten malang). Jurnal Administrasi Bisnis 41(1). Malang.

[19] Caroline A, Makkarennu, Syahidah. "Performance Measurement of Palm Sugar Business using the Integration of Supply Chain Operation Reference (SCOR) and Objective Matrix (OMAX)”. International Journal of Science and Management Studies. 4(1):7584

[20] David FR. 2006. Strategic Management. Manajemen Strategis, Konsep. Edisi 10. Terjemahan Strategic Management; Concepts anda Cases. Tenth edition. Jakarta: PT. Salemba Empat. 